\title{
TEMPAT JAJANAN MAKANAN TERAPUNG DI KAPUK
}

\author{
Natasha Intania1), Budi Adelar Sukada²) \\ 1)Program Studi S1 Arsitektur, Fakultas Teknik, Universitas Tarumanagara, intanianatasha21@gmail.com \\ 2)Program Studi S1 Arsitektur, Fakultas Teknik, Universitas Tarumanagara, budisukada@yahoo.com
}

\begin{abstract}
Abstrak
Mewujudkan tempat berkumpul, beraktivitas dan berinteraksi harus memperhatikan kebutuhan lingkungan sekitar dan juga penghuni yang akan berkunjung. Dengan melihat kebutuhan sekitar, maka Kelurahan Kapuk menjadi tempat yang membutuhkan sebuah wadah untuk memenuhi kebutuhan berkumpul, beraktivitas dan berinteraksi dan juga dengan meningkatkan kebutuhan ekonomi masyarakat sekitar.Tempat Jajanan Makanan Terapung yang letaknya masih berada di dalam Kawasan Kampung Apung merupakan wujud tempat dari sebuah kebutuhan tersebut. Tempat Jajanan Makanan ini dapat digunakan dari masyarakat yang membutuhkan tempat kerja terutama ibu rumah tangga yang menganggur dan untuk siapa saja yang hendak berkunjung. Dengan bentuk bangunan yang ikonis yang membelah jalan, terbuka dibagian tengah dan terapung yang dapat memberikan kesan seakan muncul dari permukaan air dengan bentuk seperti kerang. Dengan adanya pilihan tempat makan yang dapat berpindah- pindah berbeda dapat menjadikan tempat makan ini memiliki keunikan tersendiri. Bangunan memiliki bangunan utama yang berfungsi sebagai retail makanan dan disediakan juga beberapa tempat makan dan juga memiliki bangunan pendukung sebagai pilihan tempat makan yang disebut pod perahu yang dimana berisi area makan, area pantry dan juga area memancing. Bangunan utama dilapisi kaca agar pandangan terbuka. Struktur utama didukung oleh elips baja lengkung dan diikat oleh plat lantai. Sedangkan bangunan pendukung dapat bergerak dengan bantuan panel surya dan digerakkan oleh generator.
\end{abstract}

\section{Kata Kunci: Jajanan makanan; kebutuhan; lingkungan sekitar; terapung}

\begin{abstract}
Creating a gathering place, activities and interacting should pay attention to the needs of the surrounding environment and also the residents who will visit. By looking at the needs around, the village of Kapuk becomes a place that needs a container to meet the needs of gathering, activities and interacting and also by increasing the economic needs of the surrounding community. The floating food street where it is located in the floating village area is a place of the need. This food place can be used from people who need a workplace, especially housewives who are idle and for anyone who wants to visit. With the iconic shape of the building that divides the road, open in the middle and floating that can give the impression as if emerge from the water surface with a shell-like shape. With the choice of eateries that can be moved differently can make this place has its own uniqueness. The building has a main building that serves as a food retail and is also provided with several eateries and also has a supporting building as a dining option called a boat pod which contains a dining area, a pantry area and also a fishing area. The main building is glass coated for open view. The main structure is supported by curved steel ellipses and tied by floor plates. While supporting buildings can move with the help of solar panels and driven by generators.
\end{abstract}

Keywords: culinary; floating; move; needs; neighbourhoods 


\section{PENDAHULUAN}

\section{Latar Belakang}

Ruang publik memberikan warna sendiri dalam kehidupan masyarakat, ruang ini dibutuhkan sebagai respon terhadap ruang-ruang dalam kehidupan masyarakat seperti tempat tinggal dan tempat bekerja. Di ruang publik inilah terjadi pertukaran dan pergerakan energi yang menggerakan dan menghidupkan kawasan/lingkungan tersebut.Bentuk ruang publik yang ada merupakan gambaran nyata dari nilai-nilai kehidupan publik -privat yang dianut komunitas tersebut. Munculnya ruang publik juga merupakan respon usaha masyarakat untuk memenuhi kebutuhannya sendiri, pasar sebagai tempat bertransaksi dan memenuhi kebutuhan hidup, gedung untuk perayaan dan festival dan lain sebagainya.

Sejalan dengan perkembangan budaya saat ini, dimana masyarakat menjadi semakin tertutup (introvet), keberadaan ruang publik menjadi semakinterancam meski kebutuhan akan ruang tersebut sebenarnya masih ada. Elemen yang sering disebut/diidentifikasikan sebagai sesuatu yang hilang adalah yang oleh sosiologis Ray Oldenburd sebagai The Third Place. The Third Place (ruang/tempat ketiga) adalah ruang/tempat berkumpul/beraktivitas (gathering) komunitas masyarakat selain rumah (the first place) dan tempat bekerja (the second place).Banyak pengamat yakin bahwa hilangnya tempat komunitas untuk, berkumpul, beraktivitas dan berinteraksi inilah yang dicari oleh masyarakat yang tinggal di daerah suburban dan daerah pinggir kota (My Pad, 2005). Untuk mewujudkan tempat berkumpul maka diperhatikan kebutuhan lingkungan sekitar dan juga penghuni yang akan berkunjung. Oleh sebab itu, desain bangunan third place hasilnya untuk memenuhi kebutuhan di dalam lingkungan tersebut.

\section{Rumusan Permasalahan}

Berdasarkan latar belakang tersebut, permasalahan yang ada yaitu :

a. Apa yang harus diperhatikan untuk mewadahi third place?

b. Bagaimana solusi desain yang dapat mewadahi aktivitas third place?

\section{Tujuan}

Menciptakan proyek beserta program yang dapat mewadahi third place dengan memperhatikan kebutuhan lingkungan sekitar dan juga penghuninya. Maka desain harus bertanggung jawab dengan lingkungan disekitarnya. Selain itu, bangunan juga mempunyai solusi untuk mewadahi dan meningkatkan kegiatan ekonomi masyarakat sekitar.

\section{KAJIAN LITERATUR}

\section{Open Architecture for The Third Place}

Open Architecture adalah desain yang berkaitan dengan empati, fakta bahwa Anda menempatkan diri Anda di tempat orang-orang yang menggunakannya. Terlalu banyak arsitek sibuk dengan struktur bangunan tetapi tidak dengan manusianya. Jadi sebagian besar waktu arsitek tidak berpikir tentang bagaimana perasaan orang di bangunan mereka (Herman Hertzberger, 2016).

Menurut buku panduan STUPA 8.29 (2020), Open Architecture adalah arsitektur untuk Third Place. Open Architecture sebagai Third Place dapat diartikan dengan melihat hal-hal yang terkait dengan konteks kebutuhan masyarakat kota dan modernisasi teknologi, informasi dan individu. Konsep Open Architecture for The Third Place memiliki paradigma yaitu Openness, closness, dan voidness. Openess adalah program yang terbuka terhadap apapun (aktivitas, fungsi, pengguna, dll), sedangkan closeness program yang tertutup, diantara itu adalah voidness. 


\section{Third Place}

Dalam pembangunan komunitas, tempat ketiga adalah lingkungan sosial yang terpisah dari dua lingkungan sosial rumah ("tempat pertama") dan tempat kerja ("tempat kedua"). Contoh tempat ketiga adalah lingkungan seperti gereja, kafe, klub, perpustakaan umum, atau taman. Dalam bukunya yang berpengaruh, The Great Good Place, Ray Oldenburg $(1989,1991)$ mengemukakan bahwa tempat ketiga penting bagi masyarakat sipil, demokrasi, keterlibatan sipil, dan membangun perasaan rasa tempat. Pandangan Oldenburg tentang tempat ketiga dengan delapan karakteristik, yaitu :

a. Netral

Penghuni tempat ketiga memiliki sedikit atau tidak ada kewajiban untuk berada di sana. Mereka tidak terikat ke daerah finansial, politik, hukum, atau sebaliknya dan bebas untuk datang dan pergi sesuka mereka.

b. Leveling

Tempat ketiga tidak mementingkan status individu dalam suatu masyarakat. Status ekonomi atau sosial seseorang tidak penting di tempat ketiga, memungkinkan rasa kesamaan di antara penghuninya.

c. Percakapan adalah kegiatan utama

Obrolan menyenangkan dan bahagia adalah fokus utama dari aktivitas di tempat ketiga, meskipun tidak harus menjadi satu-satunya aktivitas.

d. Aksesibilitas dan akomodasi

Tempat ketiga harus terbuka dan mudah diakses oleh mereka yang menempatinya. Mereka juga harus akomodatif, artinya mereka memenuhi kebutuhan penghuninya, dan semua penghuni merasa kebutuhan mereka telah terpenuhi.

e. Regular Membuat yang menempati merasa aman dan tidak merasa takut.

f. Low Profile

Tempat ketiga secara karakteristik sehat. Menerima berbagai lapisan masyarakat.

g. Perasaan dan pembawaan yangmenyenangkan Memiliki sifat yang menyenangkan.

h. Jauh dari rumah

Penghuni tempat ketiga akan sering memiliki perasaan untuk menghabiskan waktu di sana.

Menurut Suwardana (2020), Third Place adalah "Neighborhood Facilities" dalam hal ini fasilitas dapat melayani 1 kelurahan. Posisinya tidak boleh berdekatan dengan jalan utama. Menurutnya, Third Place bersifat usual atau umum. Siapapun diperbolehkan datang tanpa memandang apapun. Neighborhood Facilities bersifat public, tetapi akan menjadi tidak public ketika harus berbayar. Fungsi dari Third Place harus jelas dan pengunjung dapat saling berinteraksi. Menurut Agustinus (2020) dalam paparannya, ruang ketiga dapat dilihat dalam urban design yang sangat kuat. Kata kuncinya adalah Permeabilitas yaitu merupakan rembesan dari pergerakan manusia (people movement). Menurutnya, karakter lantai dasarnya harus terbuka. Ruang ketiga dapat menjawab neighbourhood. Ruang ketiga :

a. Openess (Keterbukaan). Mempromosikan menerima berbagai orang; Mempunyai hak yang sama; Dapat menjadi tempat bertemu dengan strangers (orang asing); Permeable; Terjadi pertukaran informasi.

b. Flexibility. Mempunyai kebebasan untuk setiap orang untuk mengisi ruang tersebut; Menawarkan hybrid program (bukan program tunggal).

c. Contextuality. Autentik yang menjawab kebutuhan; Memiliki identitas lokal, kehidupan, kesehaian dan kultur.

\section{Arsitektur dalam Open Architecture}

Menurut buku panduan STUPA 8.29, open architecture menjadi kesempatan untuk menciptakan sebuah platform arsitektur yang dapat dikombinasikan dengan berbagai macam 
keadaan dan kondisi masyarakat dalam hal ini masyarakat pekotaan Jakata atau kota besar lainnya. Open architecture sebagai platform akan dibuat berdasarkan salah satu dari tiga kategori, yaitu kategori commercial, hospitality, dan entertainment. Comercial yang dimaksud disini adalah kategori yang terkait dengan aktivitas jual beli baik jasa maupun barang dan aktivitas lain yang mendukung jua beli. Hospitality merupakan aktivitas yang terkait dengan penerimaan tamu, pengunjung, dan juga pelayanan terhadap masyarakat (konsumen). Entertainment terkait dengan ekspresi, karena itu erat kaitannya dengan art dan kultur, selain itu terkadang memiliki hubungan dengan edukasi. Ketiga kategori ini dibutuhkan masyarakat terutama masyarakat kota.

\section{Tempat Jajanan Makanan}

Menurut Keputusan Menteri Kesehatan Republik Indonesia Nomor 942/Menkes/SK/VII/2003 Bab I Pasal 1, makanan jajanan adalah makanan dan minuman yang diolah oleh pengrajin makanan di tempat penjualan dan atau disajikan sebagai makanan siap santap untuk dijual bagi umum selain yang disajikan jasa boga, rumah makan/restoran, dan hotel (Docplayer, 2017). Frekuensi konsumsi subjek terhadap makanan jajanan tidak sejalan dengan tingkat kesukaan. Hal ini bisa terjadi karena dalam membeli dan mengonsumsi makanan jajanan harus didukung juga oleh ketersediaan uang jajan yang dimiliki subjek. Urutan kelompok jajanan dengan frekuensi konsumsi tertinggi hingga terendah adalah makanan digoreng, minuman, kue, jajanan sepinggan, dan buah. Makanan digoreng seperti bakso goreng, tempe goreng, chicken nugget, dan cireng, merupakan makanan yang paling sering dikonsumsi anak, yaitu rata-rata dikonsumsi subjek 7 kali per minggu, atau sekitar 1.25 kali per makanan (ada 5 jenis) dalam seminggu. Sebagaimana dinyatakan sebelumnya, umumnya subjek menyukai makanan digoreng karena rasa yang sesuai dengan selera (59.5\%). Meskipun demikian, dari unsur harga, makanan digoreng ini dipilih tertinggi (27.3\%) dibandingkan kelompok makanan lain (Leily Amalia, 2012).

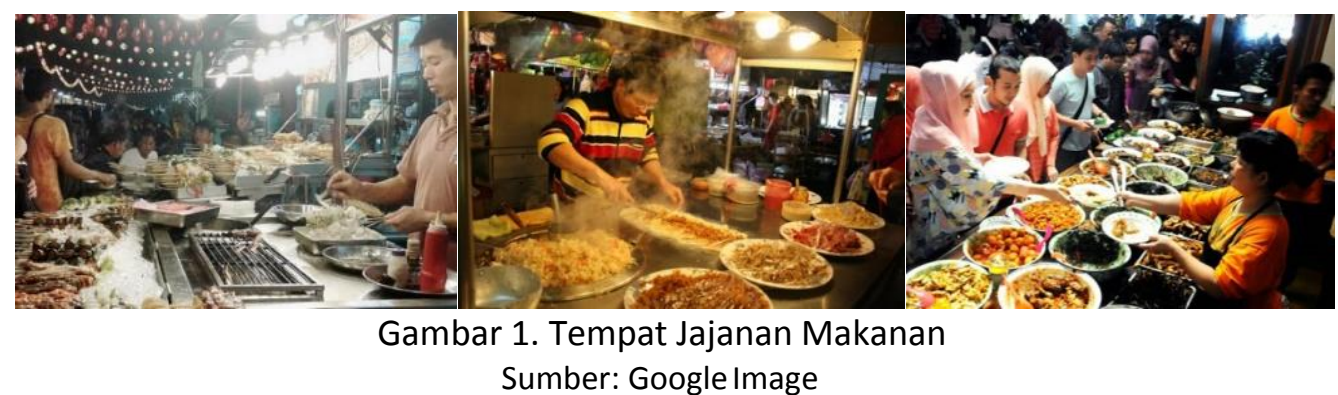

\section{Terapung}

Benda dikatakan terapung apabila massa jenis benda lebih kecil dari massa jenis zat cair, benda dikatakan melayang apabila massa jenis benda sama dengan massa jenis zat cair, sedangkan dikatakan tenggelam apabila massa jenis benda lebih berat daripada massa jenis zat cair. Di Indonesia terdapat pasar terapung yang menjual makanan. Suasana pasar terapung yang unik dan khas adalah berdesak-desakan antara perahu besar dan kecil saling mencari pembeli dan penjual yang selalu berseliweran kian kemari dan selalu oleng dimainkan gelombang sungai. Pasar terapung di Indonesia yaitu tepatnya berada di sungai barito kota Banjarmasin, Kalimantan selatan. Kegiatan pasar terapung sudah lama menjadi suatu rutinitas penduduk pesisir sungai barito pada subuh hari sampai siang hari. Perahu penjual berselaseliwir mencari pembeli karena tidak adanya tempat yang tetap untuk berkumpul melakukan kegiatan pasar ini dan juga untuk melakukan kegiatan jual beli ini harus memiliki perahu dikarenakan tidak adanya jalur darat yang dapat mengakses pasar terapung ini (Poerbantanoe, 2014). 


\section{METODE}

\section{Tempat dan Waktu Penelitian}

Penelitian dilakukan dengan mendatangi langsung Kawasan Kapuk, Jakarta Barat, tepatnya disebuah kampung yang dahulu terkenal dengan nama Kampung Teko dan kini berubah menjadi Kampung Apung, pada tanggal 18 Januari 2020. Kelurahan Kapuk menjadi tapak terpilih karena Kelurahan ini memiliki tingkat populasi usia anak 0-18thn tertinggi di Jakarta yaitu perempuan sebanyak 25.877 jiwa dan laki-laki sebanyak 27.720 jiwa dan juga memiliki satu tempat yang menarik yaitu Kampung Apung tersebut.

\section{Metode Penelitian dan Perancangan}

Metode yang dilakukan pada penelitian ini dengan melalui pendekatan kualitatif, yang menggunakan proses survey/penelitian terhadap kawasan yang diteliti. Menurut Saryono (2010), Penelitian kualitatif merupakan penelitian yang digunakan untuk menyelidiki, menemukan, menggambarkan, dan menjelaskan kualitas atau keistimewaan dari pengaruh social yang tidak dapat dijelaskan, diukur atau digambarkan melalui pendekatan kuantitatif.

Menurut Sugiyono (2011), metode penelitian kualitatif adalah metode penelitian yang berlandaskan pada filsafat post positivisme, digunakan untuk meneliti pada kondisi obyek yang alamiah, (sebagai lawannya eksperimen) dimana peneliti adalah sebagai instrumen kunci, pengambilan sampel sumber data dilakukan secara purposive dan snowball, teknik pengumpulan dengan tri-anggulasi (gabungan), analisis data bersifat induktif atau kualitatif, dan hasil penelitian kualitatif lebih menekankan makna dari pada generalisasi.

\section{Perumusan Ide}

Perumusan ide dalam merancang tempat ketiga dengan konsep "Open Architecture" didapat berdasarkan:

a. Objek

Kawasan Kapuk, Cengkareng, Jakarta Barat berbatasan dengan daerah Pantai Indah Kapuk (PIK) yang sekarang sudah ramai dengan kuliner namun dengan harga yang menengah keatas. Agar tidak menimbulkan kesenjangan social dan mewujudkan kebutuhan masyarakat kawasan Kapuk yang membutuhkan tempat makan atau kuliner (semacam food court) yang murah dan terjangkau dari segi harga. Dengan mengetahui demografi Kawasan dan juga survey lapangan bahwa terdapat anak-anak yang juga membutuhkan tempat bermain. Dan di Kampung ini menjadi objek pemancingan.

b. Tema

Dengan tema open architecture for the third place maka sarana prasarana yang dirancang harus dapat terbuka terhadap lingkungan dan masyarakat yang ada di dalam Kawasan tersebut dan menyediakan fasilitas penunjang untuk penggunanya yaitu warga pemukiman dan pekerja pabrik berdasarkan hasil observasi yang diperoleh.

c. Literatur

Literatur dapat diartikan sebagai sumber ataupun acuan yang digunakan dalam berbagai macam aktivitas di dunia pendidikan ataupun aktivitas lainnya. Literatur juga dapat diartikan sebagai rujukan yang digunakan untuk mendapatkan informasi tertentu. Literatur dapat berupa buku ataupun berbagai macam tulisan lainnya.

\section{Pencarian dan Pengolahan Data}

Jenis dan Sumber data

Data Primer dan Data Sekunder merupakan sumber-sumber data informasi yang dikumpulkan untuk menjadi dasar kesimpulan dari sebuah penelitian. Data dipeoleh dari hasil wawancara dan observasi, disertai dengan data yang diperoleh melalui studi kepustakaan. 


\section{Cara Pengumpulan Data}

a. Observasi dengan melakukan pengamatan langsung di lapangan yang meliputi proses pengamatan pola perilaku subyek (orang), obyek (benda), situasi, dan kondisi atau kegiatan sistematik tanpa adanya pertanyaan atau komunikasi dengan individu-individu yang diamati. Metode ini dilakukan tanpa perlu memberikan pertanyaan kepadanarasumber.

b. Dokumentasi merupakan kegiatan penelitian dengan mengamati berbagai dokumen yang berkaitan dengan topik dan tujuan penelitian. Dokumentasi adalah suatu teknik pengumpulan data dengan menganalisis dokumen tertulis, dan gambar.

c. Wawancara adalah percakapan dengan maksud untuk mengetahui apa yang ingin diketahui dengan metode memberi pertanyaan langsung kepada narasumber. Pada metode ini berhadapan langsung (face to face) untuk mendapatkan informasi secara lisan atau langsung dengan tujuan mendapatkan data yang dapat menjelaskan permasalahan dalam Kawasan.

d. Studi Pustaka untuk mendapatkan data-data yang dibutuhkan, baik dari teori, pendapat ahli, serta peraturan dan kebijakan pemerintah yang dapat dijadikan dasar perencanaan sehingga dapat memperdalam analisa. Data yang diperoleh dari penelusuran literatur bersumber dari data internet, buku, dan peraturan kebijakan pemerintah.

\section{Analisis Perancangan}

Dalam proses analisa, dilakukan pendekatan-pendekatan yang merupakan suatu tahapan kegiatan yang terdiri dari rangkaian pembahasan terhadap kondisi kawasan perencanaan. Semua analisa diusahakan berkaitan dengan tema utama yaitu open architecture for the third place dengan fokus pada teritorialitas.

a. Analisis Tapak

Analisis tapak yaitu analisa yang dilakukan pada lokasi dan bertujuan untuk mengetahui segala sesuatu yang ada pada tapak perancangan. Analisis ini dilakukan pada tapak yang yang berlokasi di Kelurahan Kapuk. Analisis ini meliputi analisis persyaratan tapak, analisis aksesibilitas, analisis pandangan (ke luar dan ke dalam), sirkulasi, matahari, angin, vegetasi, dan zoning.

b. Analisis Fungsi

Analisis fungsi yaitu kegiatan penentuan ruang yang mempertimbangkan fungsi dan tuntunan aktifitas yang diwadahi oleh ruang. Analisis fungsi dilakukan dengan tujuan untuk menentukan ruang-ruang yang dibutuhkan dalam perancangan Third Place, dengan mempertimbangkan pelaku, aktivitas dan kegunaan.

c. Analisis Aktivitas

Tujuan analisis aktivitas adalah untuk mengetahui aktivitas masing- masing kelompok pelaku, baik dari warga pemukiman maupun pekerja atau buruh pabrik. Dengan analisis ini ditentukan besaran kebutuhan ruang dan sirkulasi pada bangunan yang dirancang sesuai fungsi yang telah dianalisis melalui analisis fungsi.

d. Analisis Ruang

Tujuan analisis ruang adalah untuk memperoleh persyaratan-persyaratan, kebutuhan dan besaran ruang, analisis ini juga dilakukan dengan mempertimbangkan karakteristik dari Third Place agar memenuhi kebutuhan yang diinginkan.

e. Analisis Bentuk

Analisis bentuk atau bisa disebut dengan analisis fisik, yaitu analisis yang dilakukan untuk memunculkan karakter bangunan yang serasi dan saling mendukung dengan mempertimbangkan lingkungan sekitar.

f. Analisis Struktur

Analisis ini berkaitan dengan dengan bangunan, tapak dan lingkungan sekitarnya. Analisa struktur meliputi sistem struktur dan bahan (material) yang cocok untuk digunakan dalam 
perancangan bangunan yang nantinya dirancang terapung, dan analisis ini akan memunculkan rancangan yang aman bagi pengguna dan kokoh bagi bangunan tersebut.

g. Analisis Utilitas

Tujuan analisis utilitas yaitu untuk memberikan gambaran mengenai sistem utilitas yang akan diterapkan pada objek perancangan bangunan terapung. Analisis utilitas ini meliputi sistem penyediaan air bersih, sistem drainase, sistem pembuangan sampah, sistem jaringan listrik, sistem kemanan dan sistem komunikasi.

\section{DISKUSI DAN HASIL}

\section{Situasi dan Kondisi Kawasan}

Dari hasil wawancara dari beberapa warga di dalam Kampung Apung tersebut, dapat disimpulkan beberapa informasi yaitu:

Tabel 1. Kondisi Kawasan

\begin{tabular}{|c|c|}
\hline Foto & Kondisi \\
\hline & $\begin{array}{l}\text { Ketika musim hujan tiba, banjir terjadi } \\
\text { dengan ketinggian } \pm 1 \mathrm{~m}-1,5 \mathrm{~m} \text {. Ketika bencana } \\
\text { ini terjadi maka ada warga yang memilih } \\
\text { untuk mengungsi ke rumah tetangga di } \\
\text { dalam kampung tersebut yang memiliki } 2-3 \\
\text { It untuk menjadi tempat tongkrongan } \\
\text { mereka. Dan ada juga yang memilih untuk } \\
\text { mengungsi ke SD didekat Kampung Apung } \\
\text { tersebut. }\end{array}$ \\
\hline & $\begin{array}{l}\text { Untuk pekerjaan, mayoritas masyarakat di } \\
\text { Kampung Apung bekerja sebagai karyawan } \\
\text { pabrik diarea Kapuk, ada juga yang menjadi } \\
\text { karyawan pabrik di Tangerang maupun } \\
\text { Cikarang }\end{array}$ \\
\hline & $\begin{array}{l}\text { Bagi yang bekerja di daerah Kapuk masih } \\
\text { bisa dijangkau oleh angkot yang ada disana. } \\
\text { Sedangkan yang bekerja di Tangerang dan } \\
\text { Cikarang biasa menggunakan motor milik } \\
\text { pribadi. }\end{array}$ \\
\hline & $\begin{array}{l}\text { Pekerja lebih banyak menghabiskan waktu di } \\
\text { pabrik (tempat kerja). Mereka bekerja dari } \\
\text { jam 7-jam } 3 \text { atau bahkan bisa sampai jam } 4 . \\
\text { Jika lembur maka mereka pulang malam, jam } \\
\text { 7. Sedangkan para ibu banyak menghabiskan } \\
\text { di rumah Bersama anak-anaknya walaupun } \\
\text { ada juga istri yang bekerja di Pabrik. } \\
\text { Kelompok usia anak-anak mayoritas } \\
\text { bersekolah di fasilitas pendidikan terdekat. }\end{array}$ \\
\hline
\end{tabular}

Sumber: Penulis, 2020.

Dengan melihat gambar diatas, maka dapat diketahui kekurangan dan kelebihan daerah di Kalurahan Kapuk. memiliki peruntukkan lahan rata-rata untuk pemukiman dan juga pabrik. Kawasan Kapuk juga memiliki kepadatan penduduk yang sangat tinggi dan letaknya berbatasan langsung dengan Kelurahan Kapuk Muara. 


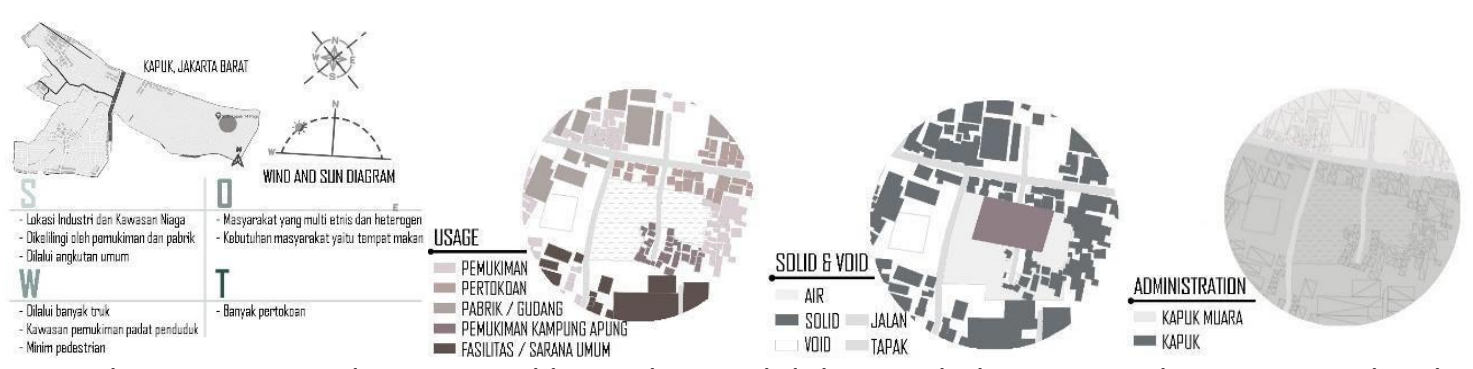

Gambar 2. S.W.O.T dan Peruntukkan Lahan, Solid dan Void, dan Batas Administrasi Wilayah Sumber: Penulis, 2020

\section{Informasi Tapak}

Secara zonasi, tapak yang dipilih berada di area zona berwarna ungu yang peruntukannya untuk zona perkantoran, perdagangan dan jasa. Total area seluruh tapak yaitu $\pm 2.885 \mathrm{~m}^{2}$. Sehingga :

a. KDB 40\% maka yang didapat sebesar $1.142 \mathrm{~m}^{2}$.

b. KLB 1,6 maka yang didapat sebesar $408 \mathrm{~m}^{2}$.

c. Dan diperbolehkan membangun dengan ketinggian bangunan 4 lantai.

d. $\mathrm{KDH} 35 \%$ maka yang didapat sebesar $999,25 \mathrm{~m}^{2}$.

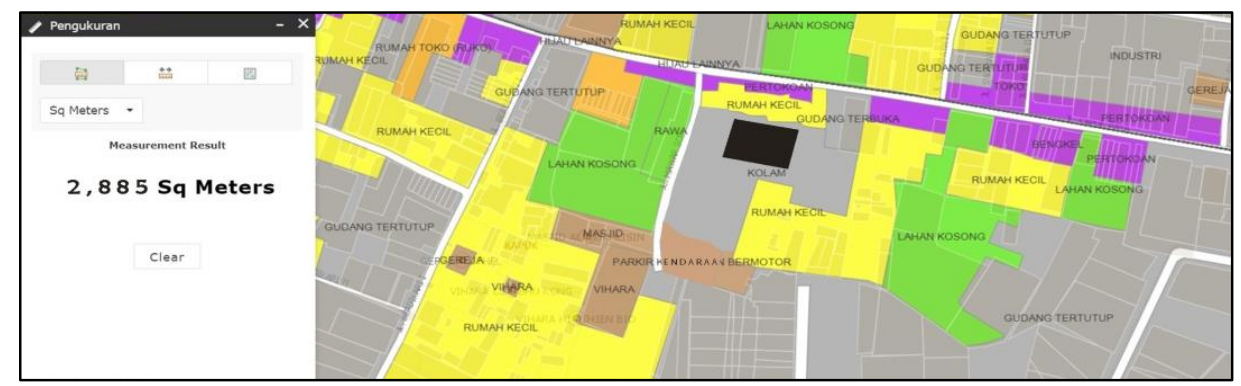

Gambar 3. Luas Tapak

Sumber: Jakarta Satu.co.id

\section{Program}

Dari hasil analisa dan wawancara, Third place yang mereka butuhkan yaitu dimana dapat mencangkup semua kebutuhan mereka, seperti tempat untuk ngobrol-ngobrol (interaksi), berolah raga (senam), dan juga yang paling penting yaitu tempat makan atau kuliner (semacam food court) yang murah dan terjangkau dari segi harga. Usulan proyek adalah pusat jajanan makanan yang didalamnya diisi oleh para ibu rumah tangga yang hasilnya untuk kebutuhan hidupnya, semacam UMKM. Usaha mikro kecil menengah atau (UMKM) adalah istilah umum dalam khazanah ekonomi yang merujuk kepada usaha ekonomi produktif yang dimiliki perorangan maupun badan usaha sesuai dengan kriteria yang ditetapkan oleh Undang-undang No. 20 tahun 2008 (Wikipedia, 2019). Bukan hanya tempat makan saja namun ditempat ini penghuni Third Place ini juga bisa memancing ikan yang nantinya akan bisa dibakar ataupun digoreng sendiri. Dengan melihat data demografi dan observasi lapangan, tingkat usia 0-18 tahun adalah yang terbanyak, oleh sebab itu maka akan diadakan fasilitas untuk mereka yaitu area bermain.

\section{Fasilitas}

Menurut Kamus Besar Bahasa Indonesia (KBBI) fasilitas adalah sarana untuk melancarkan pelaksanaan fungsi. Ada berbagai macam jenis fasilitas, yang dipakai untuk memenuhi Third Place ini yaitu fasilitas sosial. Untuk fasilitas yang akan direncanakan, yaitu :

a. Tempat jajanan makanan

Menyediakan retail makanan beserta tempat untuk makan. Berbagai macam jenis makanan baik tradisional maupun non tradisional disediakan pada tempat ini. Tempat jajanan 
makanan ini berkonsep terapung karena letaknya yang berada pada genangan air setinggi \pm 2 meter dan membentuk sebuah kolam besar dan masih berada di sekitar Kampung Apung. Konsep terapung ini diharapkan nantinya dapat menarik banyak penghuni dengan ciri khas bangunan ini.

b. Memancing

Penghuni third place dapat memancing sekaligus hasil pancingannya dapat dibakar maupun digoreng ditempat. Fasilitas ini mewadahi kebiasaan yang sebelumnya ada di area Kampung Apung tersebut. Dengan studi pustaka yang didapat bahwa di tempat ini telah disebar sebanyak 200 ikan lele.

c. Area bermain

Bukan hanya untuk orang dewasa saja, tempat ini juga didesain untuk tempat bermain anak. Dengan begitu, anak-anak yang berada di Kampung Apung maupun sekitarnya dapat menggunakan dan menikmatinya. Playground ini juga dapat melatih saraf motorik pada anak karena anggota tubuh yang bergerak aktif. Area bermain anak diisi dengan area trampoline.

\section{Konsep Desain}

\section{Bangunan Utama}

Bangunan utama yaitu bangunan inti yang ungsinya sebagai retail makanan baik tradisional maupun modern serta tempat makan. Pada desain ini bagian bangunan sebelah kiri berisi retail makanan tradisional dan sebalah kanan berisi retail modern. Kedua bangunan ini dihubungkan dengan konektor. Rumah-rumah eksisting direlokasi ke dalam kampung apung dan dengan penataan kembali kampung apung. Dengan penataan Kampung Apung kembali maka disediakan juga fasilitas umum berupa pepohonan, bangku jalan, dan tempat sampah dan juga diberi fasilitas sosial yaitu Taman Pendidikan Al-Qur'an (TPA), Rumah Belajar, dan bangunanserbaguna.

Bangunan utama juga didesain untuk menunjukkan eksistensi dengan tampilan unik yang seakan muncul dari permukaan air. Hal ini bertujuan tidak serta merta bangunan tesebut muncul tetapi seakan muncul perlahan dengan juga memperhatikan lingkungan terdekat (solusi sosial). Bentuk menyerupai kerang karena kerang merupakan hewan air yang dapat hidup pada saat pasang dan surut air. Desain ini metamorfosis dari kerang dengan harapan bangunan ini dapat beradaptasi dengan lingkungan terdekatnya (lih.Gambar 5). Memiliki dua akses masuk yaitu dari sisi utara dan sisi selatan. Area parkir diatas sebelumnya rumah warga yang direlokasi ke dalam Kampung Apung. Untuk masuk parkir dari sisi timur dan keluar dari sisi barat. Ada sekitar 38 slot parkir untuk motor serta diberi pepohonan dan juga trotoar. Disamping itu tempat ini juga dapat digunakan sebagai tempat naik dan turun pod perahu. Desain jembatan didesain salah satu fungsinya yaitu untuk pod perahu berlalu-lalang. Jembatan ini juga sebagai akses menuju bangunan dan juga Kampung Apung. Jembatan ini hanya bisa dilalui dengan berjalan kaki dan juga motor.

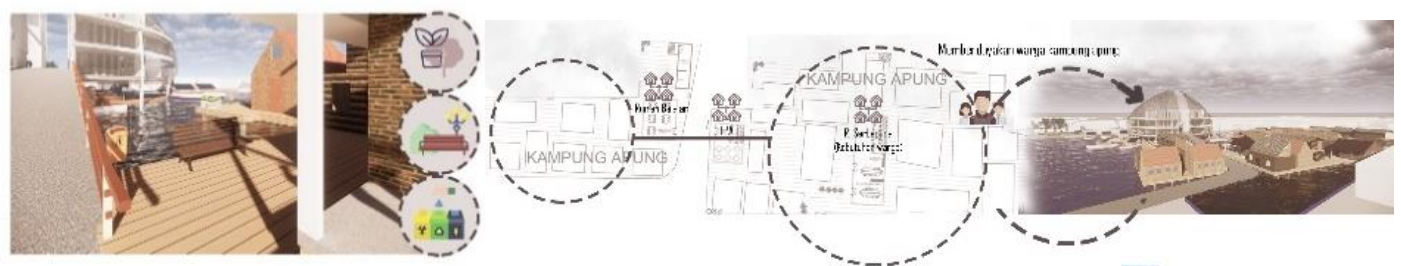

Gambar 4. Fasilitas Umum dan Sosial di Tapak Sumber: Penulis, 2020 

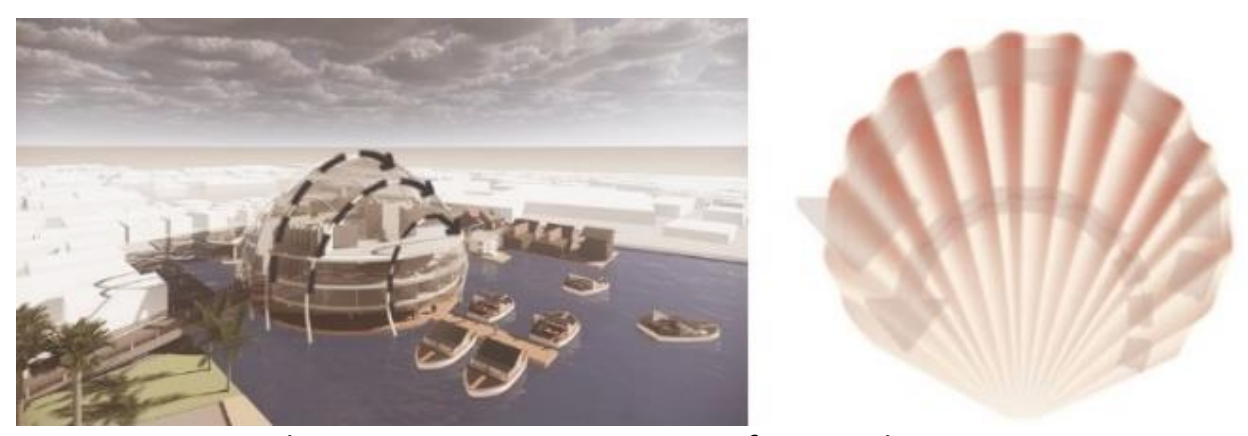

Gambar 5. Desain Bangunan Transformasi dari Kerang Sumber: Penulis, 2020

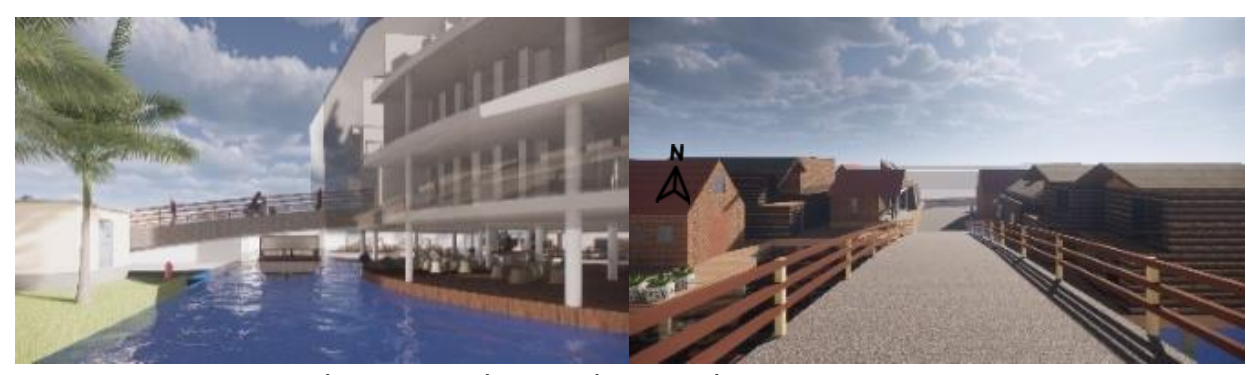

Gambar 6. Jembatan di Tengah Bangunan Utama

Sumber: Penulis, 2020
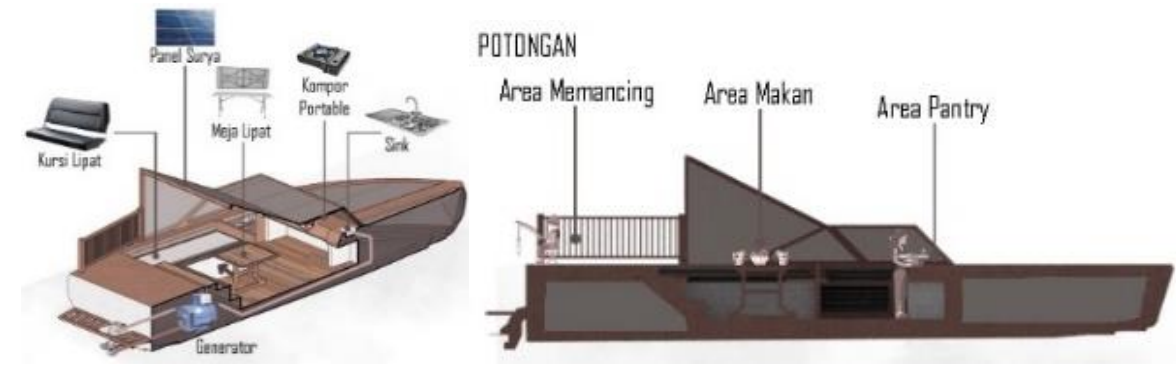

Gambar 7. Jembatan di Tengan Bangunan Utama

Sumber: Penulis, 2020

Bangunan utama menggunakan struktur elips baja lengkung sebagai pendukung pada bangunan dan diikat oleh plat lantai. Lapisan luar diselimuti dengan kaca dengan tebal kaca $5 \mathrm{~cm}$. Bangunan pendukung yaitu disebut pod perahu dapat bergerak dengan bantuan panel surya dan digerakkan oleh generator yang diletakkan di bawah deck pada tempat memancing. Panel surya juga tidak hanya dapat digunakan pada saat cuaca panas tetapi juga dapat digunakan pada saat hujan. Beban yang mengapung juga harus diperhatikan. Menurut (Arka, 2020) yaitu seorang pencetus "Rumah Amfibi" bahwa benda yang berada diatas permukaan air yang berat jenis bendanya lebih kecil dari berat jenis air. Struktur apung modular dan memliki beban berat apung $60 \%$ dari daya apung.

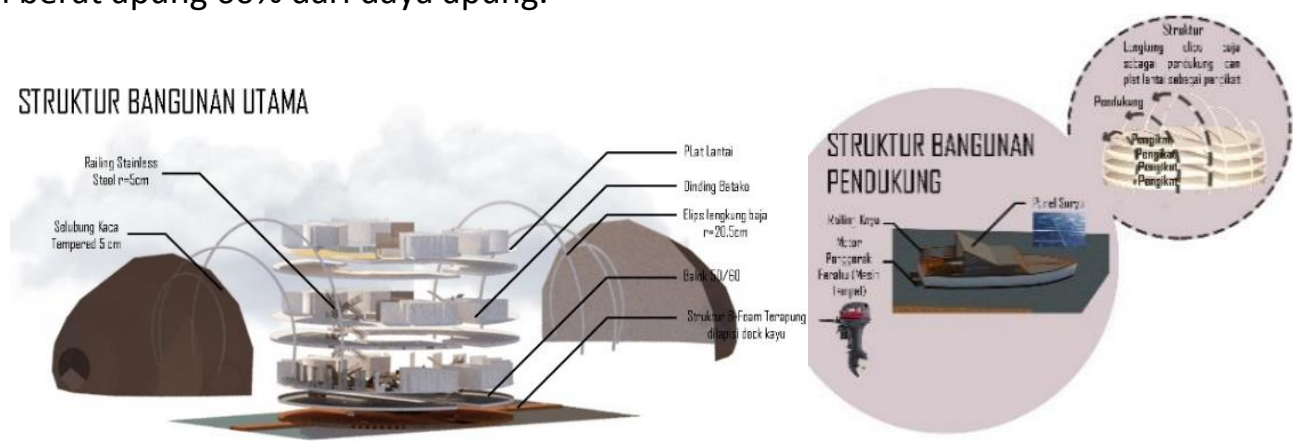

Gambar 8. Struktur Bangunan Utama dan Pendukung Sumber: Penulis, 2020 


\section{Bangunan Pendukung}

Bangunan pendukung didesain untuk mendukung bangunan utama dengan fungsi pengunjung dapat menikmati suasana terapung sambil menikmati makanannya. Dapat bergerak dengan menggunakan panel surya dan digerakkan oleh generator yang disimpan dibawah deck tempat memancing.

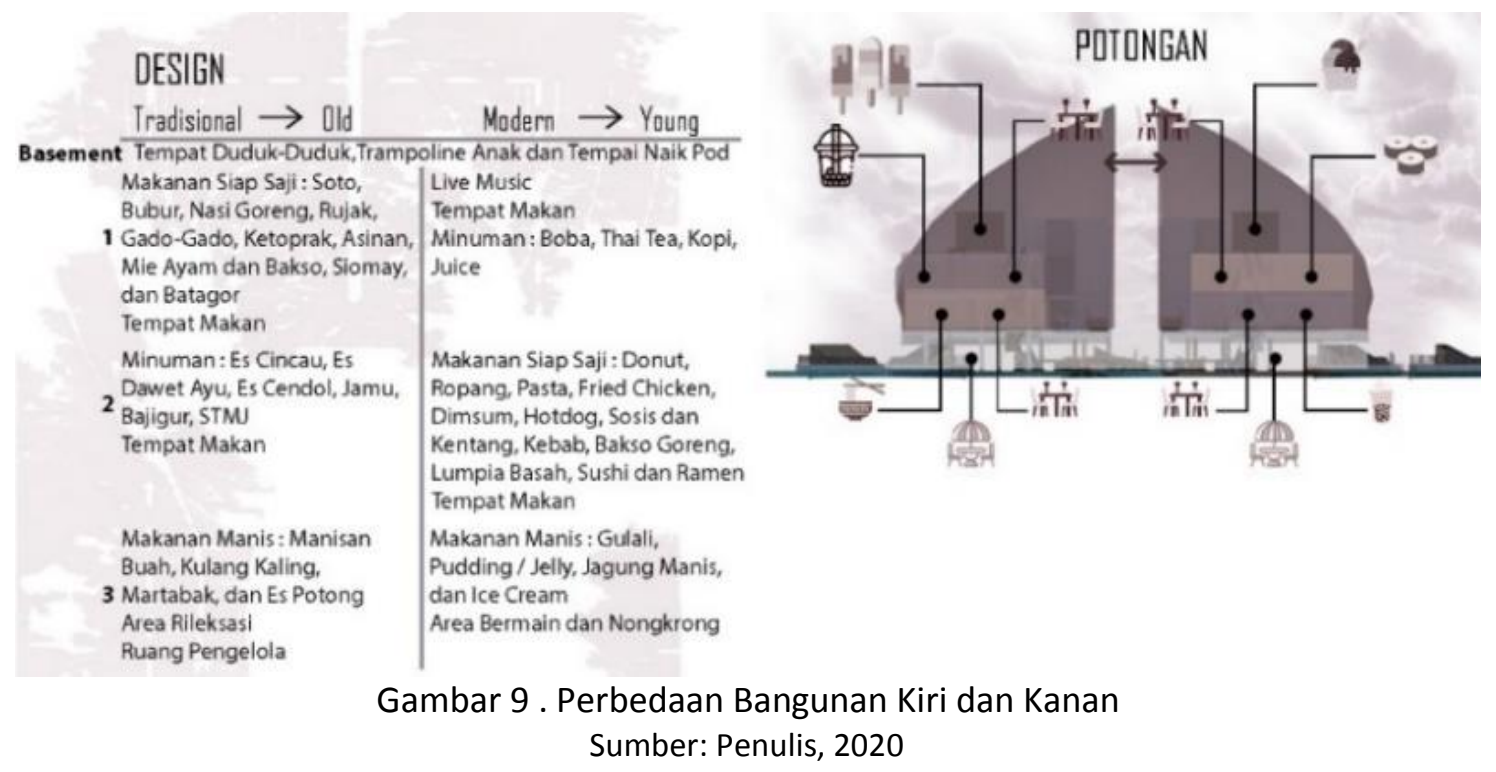

\section{KESIMPULAN DAN SARAN}

Kegiatan yang paling sering dilakukan yaitu di rumah sebagai first place, kantor dan sekolah merupakan second place dan Tempat Jajanan Makanan Terapung yaitu sebagai third place yang berada pada suatu kelurahan yaitu Kelurahan Kapuk. Tempat Jajanan Makanan Terapung ini mampu menjawab persoalan yaitu Open Architecture for The Third Place. Proyek ini mampu memenuhi kebutuhan dari first place dan juga second place dengan memperhatikan kebutuhan dilingkungan sekitar dan juga meliputi satu kelurahan. Dengan adanya bangunan ini maka masyarakat tidak perlu jauh-jauh lagi untuk ke tempat makan.

Dengan desain yang unik, Tempat Jajanan Makanan Terapung ini dapat menarik penungunjung untuk datang. Bukan hanya desainnya saja yang menarik, namun juga terdapat progam yang unik dengan cara makan di dalam pod perahu yang dapat berkeliling pada area yang terkena dampak genangan air tersebut. Proyek ini juga menjadi wadah bagi para pekerja yang membutuhkan tempat kerja dengan keahliannya dalam bidang memasak dan berdagang dengan sistem UMKM. Diharapkan nantinya proyek ini dapat menjadi acuan untuk membangun third place dengan memperhatikan lingkungan sekitar yang terdekat.

\section{REFERENSI}

Arka, W. (2020, Januari 24). Bangunan Terapung. (N. Intania, Interviewer)

Designboom. (2014). Designboom. Retrieved July 4, from

https://www.designboom.com/architecture/spark-architects-floating-hawker-centresolar-orchid-singapore-07-04-2014/

Docplayer. (2017). Html. From Docplayer: https://docplayer.info/32067543-Keputusanmenteri-kesehatan-republik-indonesia-nomor-942-menkes-sk-vii-2003-tentang-pedomanpersyaratan-hygiene-sanitasi-makanan-jajanan.html

Julianti, U. W. (n.d.). Pengaruh Model Project Based Learning Berbantuan. Jurnal Pendidikan Fisika Tadulako (JPFT), 9-10.

Leily Amalia, O. P. (2012). PREFERENSI DAN FREKUENSI KONSUMSI MAKANAN JAJANAN PADA 
ANAK. Jurnal Gizi dan Pangan, 124.

My Pad. (2005). Html. Retrieved September 2, from My Pad:

http://jiwangga.com/MyPad/Entries/2005/9/2_Kebutuhan_Ruang_Ketiga.html

Poerbantanoe, T. A. (2014). PASAR TERAPUNG DI BANJARMASIN,. JURNAL eDIMENSI

ARSITEKTUR, 336-337.

Wikipedia. (2006). Wikipedia. From Wikipedia: https://en.wikipedia.org/wiki/Third_place

Wikipedia. (2019). Wikipedia. From Wikipedia:

https://id.wikipedia.org/wiki/Usaha_mikro_kecil_menengahhttps://id.wikipedia.org/wiki/ Usaha_mikro_kecil_menengah 